\title{
Calculating Probable Theoretical Offspring Genotype in Fruit Flies
}

Megan Keller

University of South Florida, megankeller1@usf.edu

Advisors:

Arcadii Grinshpan, Mathematics and Statistics

Johnny El-Rady, Cell Biology, Microbiology and Molecular Biology

Problem Suggested By: Felix Green

Follow this and additional works at: https://digitalcommons.usf.edu/ujmm

Part of the Mathematics Commons

UJMM is an open access journal, free to authors and readers, and relies on your support:

Donate Now

\section{Recommended Citation}

Keller, Megan (2021) "Calculating Probable Theoretical Offspring Genotype in Fruit Flies," Undergraduate Journal of Mathematical Modeling: One + Two: Vol. 11: Iss. 2, Article 4.

DOI: https://doi.org/10.5038/2326-3652.11.2.4932

Available at: https://digitalcommons.usf.edu/ujmm/vol11/iss2/4 


\title{
Calculating Probable Theoretical Offspring Genotype in Fruit Flies
}

\author{
Abstract \\ Being able to calculate an offspring's theoretical genotype is critical in genetic sciences. We calculate the \\ theoretical genotype and phenotype of fruit fly offspring. Using the product rule, we determine the \\ probability for each trait and then for each genotype. In conclusion, we calculate 64 different genotypes \\ that are supposed to be possible, but only 8 phenotypes are possible.
}

\section{Keywords}

fruit fly, offspring, genotype, phenotype, product rule, Punnett square

Creative Commons License

(c) (i) (9)

This work is licensed under a Creative Commons Attribution-Noncommercial-Share Alike 4.0 License. 


\section{PROBLEM STATEMENT}

Determine the expected phenotypes of the offspring of fruit flies grown in the lab. Compare theoretical and observed phenotypes.

\section{Motivation}

Humans have been selectively breeding different organisms for thousands of years. From plants to dogs, we can select and try to encourage beneficial traits in these organisms by breeding selected individuals together. Genes are units of heredity that determine the characteristics of an organism, and are past down from parent to offspring. During conception, gametes from both parents, containing only half of the parents' genes known as a haploid, fuse together to create a full set of genetic material and produce a diploid zygote. Because of this, the offspring will contain a combination of both parents' genes; the blending of genes can result in traits that are different from either parent. By understanding how offspring inherit traits from their parents, we can determine how genes are recombined and interact.

\section{MATHEMATICAL DESCRIPTION AND SOLUTION APPROACH}

In the lab, we are provided 20 fruit flies (Drosophila melanogaster), 15 females of which exhibit wild type phenotypes and 5 males which exhibit mutant allele types. The wild type alleles are dominant to the mutant; this dominance will affect phenotype expression. The parental generation's genomes can be simplified as:

$$
A^{+} A B^{+} B C^{+} C \times A^{+} A B^{+} B C^{+} C
$$

To determine the probability of each trait, we construct a Punnett square; this helps to visualize genetic recombination of the offspring. 


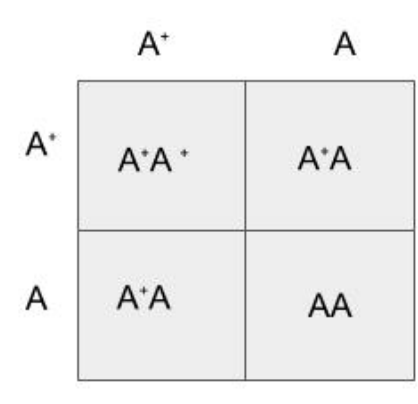

$$
\begin{aligned}
& A^{+} A^{+}=1 / 4 \\
& A^{+} A=1 / 2 \\
& A A=1 / 4
\end{aligned}
$$

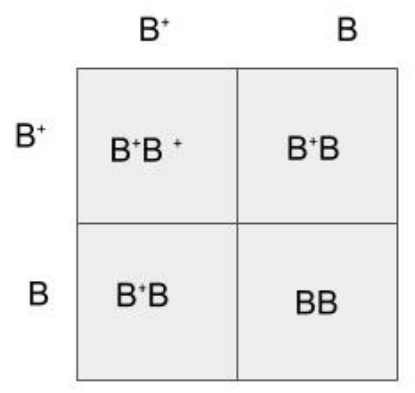

$\mathrm{B}^{+} \mathrm{B}^{+}=1 / 4$

$B^{+} B=1 / 2$

$\mathrm{BB}=1 / 4$

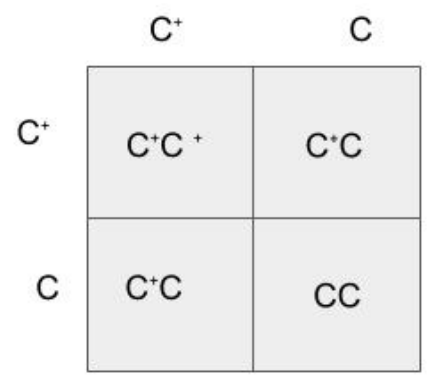

$\mathrm{C}^{+} \mathrm{C}^{+}=1 / 4$

$\mathrm{C}+\mathrm{C}=1 / 2$

$\mathrm{CC}=1 / 4$

Figure 1: Punnett Squares for F1 generate cross breeding

The first equation used is the product rule, which is used to determine the probability of an offspring's phenotype based on the sum of each trait's individual probability.

The expression can be written as:

$$
P_{\mathrm{p}}=P_{1} * P_{2} * \ldots * P_{\mathrm{n}}
$$

All genes with at least one wild type allele will express the wild type phenotype, because offspring with the same traits may have different genomes (Table 1).

\section{DISCUSSION}

Once we establish the probability for each genome independently we then can calculate the probability for each genome combination.

$$
\begin{gathered}
A^{+} A B^{+} B C^{+} C=(1 / 2) *(1 / 2) *(1 / 2)=1 / 8=12.5 \% \\
A A B^{+} B^{+} C^{+} C^{+}=(1 / 4) *(1 / 4) *(1 / 4)=1 / 64=1.56 \%
\end{gathered}
$$


In total there are 64 different genomes possible for an offspring from cross breeding $A^{+} A B^{+} B C^{+} C$ flies. But only 8 different phenotypes are possible due to the dominance of the wild type allele. Based on these calculations we can predict that the most common phenotype for the offspring will be gray bodies, red eyes and long wings. Once the offspring have matured and their traits observed and recorded, those observations can be compared to the theoretical data, this can be useful in determining if an allele is dominant or recessive or codominant (Table 2).

\section{CONCLUSION}

Being able to predict the probable genome of offspring is a useful tool in genomic sciences. Although a three trait cross is relatively basic, these methods are used in genetic counseling for family planning and for breeding desirable traits in livestock.

\section{REFERENCES}

Brooker, R. J. (2017). Chapter 2: Mendelian Inheritance. In Brooker Genetics, 6th edition (pp. 33-39). Place of publication not identified: McGraw-Hill Education.

Staroscik, A. (2020). Punnett square for phenotype of three trait cross [Digital image].

Retrieved from https://scienceprimer.com/punnett-square-calculator

Wray, N., Ph.D. (2008). Estimating Trait Heritability. Retrieved December 04, 2020, from https://www.nature.com/scitable/topicpage/estimating-trait-heritability-46889/ 


\section{APPENDIX}

Table 1:

\begin{tabular}{|c|c|c|}
\hline Genotype & Probability & Trait \\
\hline$A^{+} A^{+}, A^{+} A$ & $3 / 4$ & Gray body \\
\hline$A A$ & $1 / 4$ & Black body \\
\hline$B^{+} B^{+}, B^{+} B$ & $3 / 4$ & Red eyes \\
\hline$B B$ & $1 / 4$ & Sepia eyes \\
\hline$C^{+} C^{+}, C^{+} C$ & $3 / 4$ & Long wings \\
\hline$C C$ & $1 / 4$ & Miniature wings \\
\hline
\end{tabular}

Table 2:

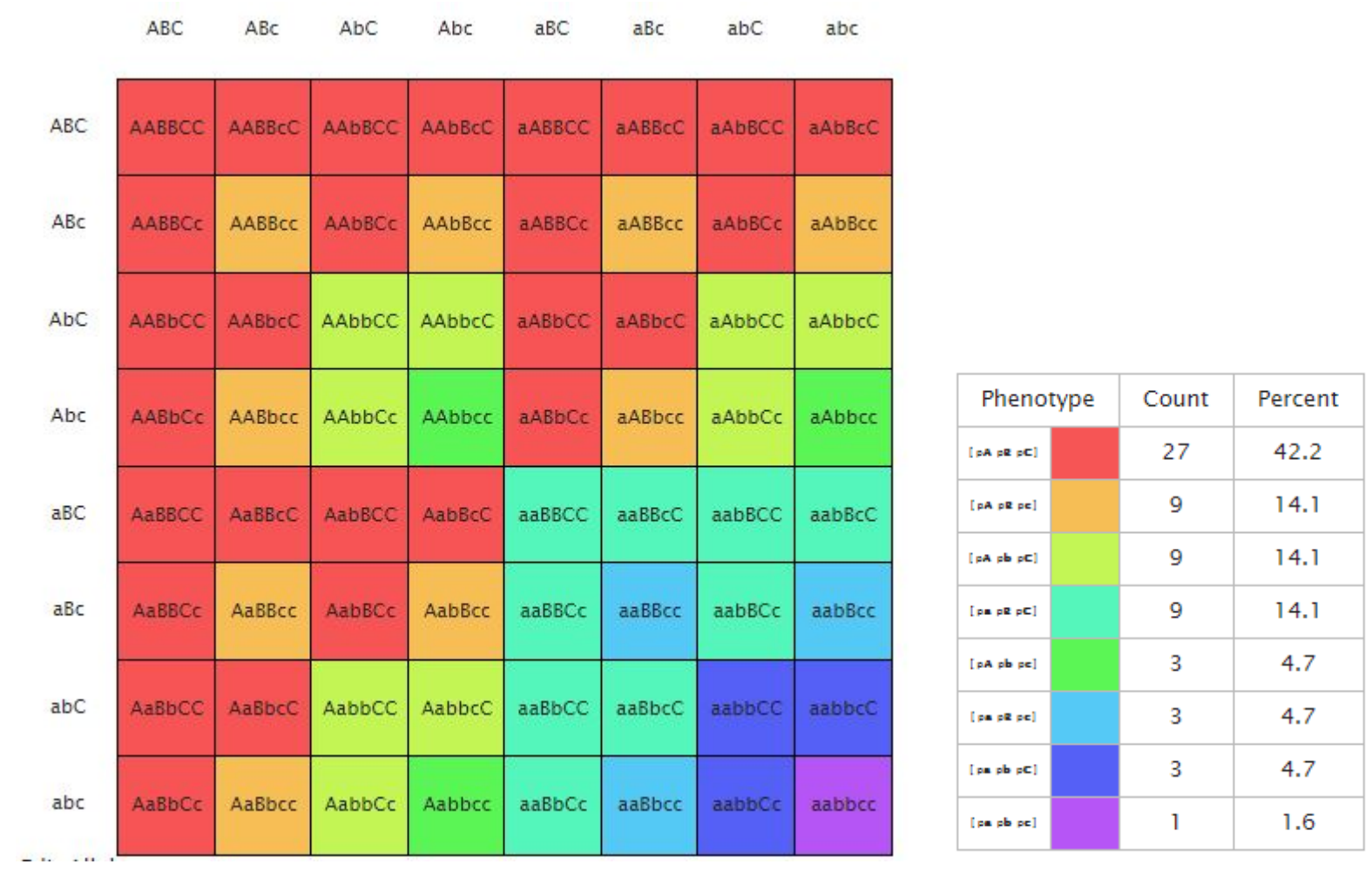

